\title{
The Effect of Role-Play Learning Strategy and Self-Concept on Social Skills of Children Age 5-6 Years Old in Aisyah Az- Zahra Medan
}

\author{
Syamsu Nahar ${ }^{1}$, Wahyuddin Nur Nasution ${ }^{2}$, Sunita Sari ${ }^{3}$ \\ 1,2,3Faculty of Tarbiyah and Teacher Training, Universitas Islam Negeri Sumatera Utara, Indonesia \\ Email: sunitasari44@gmail.com
}

\begin{abstract}
This study aims to determine: (1) differences in the social skills of children who carry out learning activities using macro role playing strategies and those using micro role playing, (2) differences in social skills of children who havehigh self-concept and children who have low self-concept, and (3) the interaction between role playing strategies and self-concept on social skills. The populations in this study were children aged 5-6 years. This research was conducted at PAUD Aisyah Az-zahra Medan. The research method used was quasiexperimental. The collection technique was a questionnaire and a test, then the data analysis technique was a two-way analysis of variance. The results showed (1). the average social skills of children who learn to use macro role playing strategies are higher, namely $=8.80$ compared to those who use micro role playing strategies $=6.50$, with $f$-count $=9.096>f$-table $=3.48$, with a level significant $0.05,(2)$ the average social skills of children who have high self-concept is higher with an average $=9.15$ while the average social skills of children who have low selfconcept $=7.96$ with $f$-count $=5,967>$-table $=3.48$ with a significant level of 0.05 , and (3) there is an interaction between playing with self-concept on children's social skills with $f$ count $=4.591>$ f-table $=3.48$ at a significant level of 0,05 .
\end{abstract}

Keywords: macro role playing method; self concept; social skills

\section{Introduction}

One aspect of growth and development that can be stimulated in early childhood is the aspect of social skills. The importance of the aspect of social skills because social skills are part of the overall intelligence of children related to children's lives. The aspect of social development is the child's ability to relate or establish good relationships with other people and be able to adapt to the surrounding environment.

Children can learn effectively and can develop all aspects of development in children including aspects of social skills, so it is necessary to choose learning strategies that are appropriate to the child's world. Learning should be able to provide opportunities for children to be active in that learning.

\section{Review of Literatures}

Sidarta in Desti (2013:237) states that social skills are individual skills in starting or maintaining a positive relationship in social interaction. Social skills can also be interpreted as an important role in forming positive friendship relationships that need to be learned from an early age. In line with Ormrod (2008:89) states that social development is marked by the development of a deeper understanding of other people and society as a whole and also the development of more effective interpersonal skills and more internalized standards of behavior as we age. 
This is also in line with the opinion expressed by Masganti (2012:106) that humans are social creatures who cannot live alone, they need interaction with other humans. Social interaction is a natural need that is owned by humans. Examples of social skills are: Communication, cooperation, assertion, responsibility, empathy, engagement and self control.

Merrel (2008) explains the notion of social skills as specific behavior, initiative, and leading to expected social outcomes as a form of one's behavior. It is different from Matson and Ollendick in Widyanti (2008: 48) that social skills are a person's ability to adapt well to their environment and avoid conflict when communicating both physically and verbally. Abdurahman (2020) states that Social relationships are reciprocal relationships between individuals with each other, influence each other and are based on awareness to help each other.

The social characteristics of early childhood according to Patmonodewo (2016:33) are as follows: (1) children have one or more friends, but the friends quickly change. They are generally quick to adapt socially, they want to play with friends. (2) the play groups tend to be small and not well organized, therefore they are easy to change; (3) weak children often play next to older children; (4) play patterns that vary according to social class and gender; (5) disputes often occur but after a while they will return to normal; (6) have realized gender differences. Furthermore, the form of social behavior according to Masganti (2012: 106) is as follows: (1) negativism, (2) aggression (3) clashing (4) teasing (5) rivaly (6) cooperation (7) ascendant behavior, (8) selffisness, and (9) sympaty.

Factors that can hinder or hinder children's social development are as follows: (1) lack of opportunities to socialize, can be caused by parents and family members who do not have the time and attitude of parents who are too protective, (2) low self-motivation, caused by children who withdraw from the environment because they are not satisfied and the child becomes the target of ridicule, (3) excessive dependence, children who are too dependent on their parents will be hampered by their social development, (4) excessive adjustment in the hope that this will guarantee their acceptance, (5) low self-adaptation, because the child does not have the motivation to adjust and the child lacks knowledge of group expectations, (6) prejudice, for children who are prejudiced will be cruel and intolerant while the child victim of prejudice becomes aggressive and thinks that the environment socially hostile to them. (Hasnida, 2015: 40).

Social skills for children have many benefits, including according to Azzet (2020: 43), which are as follows: (1) healthy body and soul, the mental state of the child is closely related to the state of his body. (2) create a comfortable atmosphere, children who have good social skills will be able to make the atmosphere comfortable, a comfortable atmosphere will make one's relationship with others good, (3) arouse enthusiasm, (4) calm fights.

Hurlock in Meta (2016: 27) argues that self-concept is a picture that a person has about himself which is a combination of beliefs about himself, physical, psychological, social, emotional characteristics and achievements. Furthermore, Yamin (2013: 91) also suggests that self-concept includes all individual views about the physical dimension, personal characteristics, motivation, weaknesses, intelligence, failures, and so on.

Self-concept can be distinguished as follows: (1) high self-concept, namely positive self-concept, positive self-esteem, and positive self-acceptance. So it follows that self-concept is synonymous with self-attitude and feelings of self-worth. Hurlock (2007: 89) states that a 
child who has a high self-concept will develop self-confidence, independence, and the ability to see themselves real or realistically and have high self-esteem. Abdussalam (2012:64) says that students who have high self-esteem are more likely to succeed in school. Besides that, they also have positive thoughts about school, behave positively in class, and are liked by other friends, and (2) low self-concept as a negative self-concept or negative assessment.

The characteristics of people who have low self-esteem are, lack of confidence, and tend to have bad hopes, less effort at assignments, less success in their careers and relationships with other people. Apart from that, someone who has a low self-concept always feels anxious, always feels insecure in dealing with other people and is very shy (Abdussalam, 2012: 64).

Piaget in Khadijah (2016: 87) states that playing activities is an exercise to consolidate various new knowledge and skills so that they can function properly. Playing is an activity that is very important for children's growth and development. Playing is done without coercion so that playing becomes fun and will result in a learning process in children. (Mutiah, 2010: 140).

Sujiono and Yuliani (2010:36-37) state that there are several functions of play in early childhood, namely: (1) it can strengthen and develop muscles and coordination through movement, train gross motor skills, train fine motor skills, and balance, because when children play of course they will learn how their body works, (2) can develop their emotional skills, self-confidence in others, courage and independence to take the initiative because when playing children often pretend to be someone else, an animal and so on, (3) can develop their cognitive abilities, because by playing children often explore something in the surrounding environment as a form of curiosity, and (4) can develop children's independence, because when playing children often ask questions, learn to make decisions, and practice social roles so that children realize their abilities and strengths.

Syukri (2019: 163) explains the role playing method emphasizes the reality where children are involved in playing a role in dramatizing social relationship problems. Furthermore, Handayani (2016: 6) states that through the role playing method the child will express himself according to the role the child will play and the child can express his feelings.

According to Sugiharto (2020) Education is one of the efforts to improve the ability of human intelligence, thus he is able to improve the quality of his life. So, to create the highest quality of human resources, education is becoming an important factor to be considered.Isjoni (2010: 65) states that role playing is the presentation of material by showing demonstrations, both in the form of descriptions and in reality. Everything is in the form of behavior in social relationships which is then asked by several students to act it out.

\section{Research Methods}

The quantitative research method is a quasi-experimental method using a $2 \times 2$ factorial design. The sample consisted of 15 students in the experimental class and 15 students in the control class. The experimental class was subjected to treatment of playing macro roles while in the control class it was subjected to treatment of playing micro roles. The data collection instruments were questionnaires and tests. The data analysis technique used was two-way analysis of variance at $\alpha 0.05$. 


\section{Disscussion}

The results of the $2 \times 2$ factorial ANOVA calculation obtained F-count $=9.096$ while F-table $=3.48$ for $\mathrm{dk}(1)$ with a significant level of 0.05 . So it turns out that the value of Fcount $=9.096>$ F-table $=3.48$, and it can also be seen from the significant value $<0.05$, the test of this study was declared significant, namely $0.006<0.05$. Thus, it can be concluded that social skills by playing macro roles are higher than children's social skills by playing micro roles.

Based on the results of testing children's social skills with learning activities using macro role playing strategies, it was found that an average of $=8.80$, while children's social skills using micro role playing strategies were $=6.53$. From the average results, it can be seen that the social skills of children with learning to play macro roles are higher/better than those of social skills by playing micro roles. It can be understood that playing macro roles is playing real / direct roles for children who play a role in these activities. Thus the child will experience direct experience playing the role/character he plays. Role playing is a variety of fun activities for children. In playing, children can carry out various activities that can stimulate children's growth and development.

As the findings of Nirwana's research (2019: 15) that playing macro roles with children's language skills states that groups of children who take learning with the macro role playing method are included in the high category. This because when children play macro roles the children will indirectly be involved in question and answer conversations in role playing. The child's ability to arrange words and speak and how to interact with interlocutors can be better.

The results of this study are also supported by research by Khumaira (2015) in her journal entitled the effect of the macro role playing method on aspects of language development for children aged 5-6 years, as we know that good language skills are also part of social skills, where in In this journal, there is a conclusion that playing macro roles is very influential on children's language skills, and it is also said that playing macro roles has a positive and significant relationship to the aspects of early childhood language development.

Thus it is known that the first hypothesis, namely the social skills of children by playing macro roles are higher than the social skills of children with micro role playing activities. This is also in accordance with the theory conveyed by Diana Mutiah (2010: 115) that playing macro a role is that children have a real role and become someone or something. When children have daily experiences with playing macro roles, they will learn a lot like children will play the role they want to be. For example, playing a role as father, mother, doctor, police, and machinist and so on.

The results of the $2 \times 2$ factorial anova calculation obtained F-count $=5.967$ while the F-table $=3.48$ for $\mathrm{dk}(1)$ with a significant level of 0.05. So it turns out that the value of Fcount $=5.967>$ F-table $=3.48$, and it can also be seen from the significant value $<0.05$, this test is declared significant, namely $0.022<0.05$. So thus it can be concluded that the social skills of children with high self-concepts are higher than children with low self-concepts.

The social skills of children who had a high self-concept based on the test results of the study got an average of $=9.15$, while the social skills of children who had low self-concept were $=7.96$. The result data shows that the social skills of children who have high selfconcept are higher than the social skills of children who have low self-concepts. 
Burns (1993) states that the self-concept is centered on the experience of each individual and is always ubiquitous in every aspect of behavior, acting as an intermediary both as a stimulant and a response. In this study, self-concept becomes a source of support for a child to do what he wants to do and is free to choose. Self-concept is support to do as you wish which ultimately brings satisfaction to learning, where this satisfaction can have an influence on children's self-concept.

The self-concept is formed as a result of a person's interaction with people who are meaningful in his life. Relationships with meaningful people have a big influence on the formation and development of a child's self-concept. So it can be formed a self-concept that tends to be high (positive), and tends to be low (negative), in a child. A child who has a high self-concept will have characteristics, namely: having self-confidence, appreciating physical abilities, being able to adapt well to friends and family, being responsible, and achieving.

The results of this study are also supported by the results of research by Agustriana (2013: 275) that there are significant differences in the social skills of children with a positive / high self-concept compared to children who have low/negative self-concepts.

The results of the $2 \times 2$ factorial anova calculation, the results obtained $\mathrm{F}$-count $=$ 4.591, while the F-count $=3.48$ with dk (1) with a significant level of 0.05 . So that the value of F-count $=4.591>$ F-table $=3.48$. Thus it can be concluded that there is an interaction between role playing strategies and self-concept in influencing early childhood social skills.

The results showed that there was an interaction between role playing strategies and self-concept on children's social skills. Children with high self-concept and given macro role playing activities have higher social skills than children who have low self-concept and are given macro role playing activities. Likewise, children who have low self-concept are given higher macro role playing than children who have low self-concept and are given micro role playing activities.

The results of the acquisition of children's social skills will be better when using a strategy of playing macro roles compared to playing micro roles. This is because playing macro roles provides direct experience for children to interact with other friends. However, the children's social skills cannot be improved only by playing roles but also supported by factors such as high self-concept. So it is necessary to have good cooperation between teachers and students in learning so that the expected learning objectives can be achieved.

The results of this study are also supported by Abidin's research (2016) in his journal entitled increasing social skills through role playing with the conclusion that the application of role playing methods in improving children's social skills shows an increase, compared to before using roles. Before using the role-playing method, the children's social skills were lacking in several social skills, namely the lack of children's care for friends, lack of respect for friends, lack of sharing with friends. Then, after going through the third cycle stage, a change in the improvement of the children's social skills is seen.

Likewise, Lestari's research (2018) shows that the application of role playing methods can improve social skills, this is because there are several indicators that can be achieved by children such as being able to be cooperative, being able to show tolerant attitudes, being able to express emotions and others. 


\section{Conclusion}

Based on the research findings, it can be concluded as follows: (1) there are differences in the social skills of group B children who learn using macro role playing strategy activities and micro role playing strategies. The results of the analysis of variance show that the value of f-count $=9.096>$ f-table $=3.48$, with a significant level of 0.05 . The social skills of children with macro role playing activities are higher than those with micro role playing strategies, (2) there are differences in the social skills of children who have high self-concept with children who have low self-concepts. The results of the analysis of variance show that $f$-count $=5.967$ $>$ f-table $=3.48$, with a significant level of 0.05 . The social skills of children with high selfconcept were higher than those with low self-concepts, and (3) there was an interaction between role playing strategies and self-concept. Children who have high self-concept gain better social skills if given macro role playing activities, while children who have low selfconcept gain good social skills if given micro role playing activities. The results of the analysis of variance show that $\mathrm{f}$-count $=4.591>\mathrm{f}$-table $=3.48$ at a significant level of 0.05 .

\section{References}

Abdurrahman, Jaya, I., and Azhari, M.T. (2020). Social Relations of Mathematics Education Students North Sumatra State Islamic University Medan withSociometry Assisted. Britain International of Linguistics, Arts andEducation(BIoLAE) Journal Vol. 2 (2): 552-559.

Akhmad Muhaimin Azzet. Mengembnagkan Kecerdasan Sosial Bagi Anak, Yogyakarta: Kata Hati.

Diana Mutiah. Psikologi Bermain Anak Usia Dini, Jakarta: Kencana, 2010.

Elizabeth B. Hurlock. Personality Development,New York: MCGraw Hill Comapany inc. 2007.

Hasnida. Analisa Kebutuhan Anak Usia Dini, Jakarta: Luxima Metro Media, 2015.

Isjoni. Strategi Bermain Peran, Cet II, Jakarta: Rajawali Press, 2010.

Jeanne Ellis Ormrod. Psikologi Pendidikan : Membantu Siswa Tumbuh dan Berkembang, Erlangga, 2008.

Khadijah. Pengembangan Kognitif Anak Usia Dini, Medan: Perdana Pubishing, 2016.

Khumaira. Pengaruh Metode Bermain Peran Makro Terhadap Aspek Perkembangan Berbahasa Anak Usia 5-6 Tahun, Universitas Lampung, 2015.

Martinis Yamin. Panduan Pendidikan Anak Usia Dini, Jakarta: Gaung Persada Pressa, 2013.

Masganti. Perkembangan Peserta Didik, Perdana Publishing, Medan: 2012.

Merrel. Social Skill.2008,http//id.shvoong.com/ social sciencepsychology/ pengertian keterampilan sosial.

Meta. Pengaruh Bermain Konstruktif dan Konsep Diri Terhadap Perolehan pengetahuan (Penelitian Kuasi Eksperimen di TK Methodist Brastagi) Medan: Unimed, 2016.

Nesna Agustriana. Pengaruh Metode Edutainment dan Konsep Diri Terhadap Keterampilan Sosial Anak, Jurnal Pendidikan Anak Usia Dini, Vol.7, Edisi 2, November 2013.

Nirwana. Penerapan Metode Bermain Peran MakroTerhadap Kemampuan Berbicara, Jurnal Instruksional. Vol.1,No.1, Oktober 2019, STKIP Kusuma Negara Jakarta.

Patmonodewo. Pendidikan Anak Prasekolah, Jakarta: Rineka Cipta, 2016.

Pujiati Desti. Peningkatan Keterampilan Melalui Metode Bermain Peran, Universitas Negeri Jakarta, Jurnal Pendidikan Anak Usia Dini, Volume 7 Edisi 2, 2013.

Ratno Abidin. Peningkatan Keterampilan Sosial Melalui Metode Bermain Peran Drama Pada Siswa Kelompok B di TK Aisyiyah Bustanul Athfal 58 Surabaya, Jurnal Pedagogi, Vol.2, No.3 Agustus 2016. 
Rusydi Ananda. Perencanaan Pembelajaran. Medan: LPPPI, 2019.

Sugiharto (2020) Geographical students' learning outcomes on basic political science by using cooperative learning model with Group Investigation (GI) type in State University of Medan, Indonesia, Journal of Human Behavior in the Social Environment, 30:4, 447456, DOI: 10.1080/10911359.2019.1696261.

Sujiono dan Yuliani Nurani. Konsep Dasar Pendidikan Anak Usia Dini, Jakarta: Indeks, 2010.

Suroso Abdussalam. Cara Mendidik Anak Sejak Lahir Hingga TK, Surabaya: Sukses Publishing, 2012.

Widyanti, Meningkatkan Keterampilan Siswa Terisolir di Sekolah Dasar Dengan Permainan Tradisional, Program PPB UPI Bandung, 2008. 